\title{
THE ASSOCIATION BETWEEN VITAMIN D VALUES AND PSORIASIS: A LITERATURE REVIEW
}

\section{Zamfirescu Mihaela', Ghiță Nicolae-Alexandru², Chirilă Sergiu1', Gurgaș Leonard', Hangan Tony'}

${ }^{1}$ Faculty of Medicine, University "Ovidius" of Constanta

${ }^{2}$ County Emergency Clinical Hospital "Sf. Apostol Andrei" Constanta

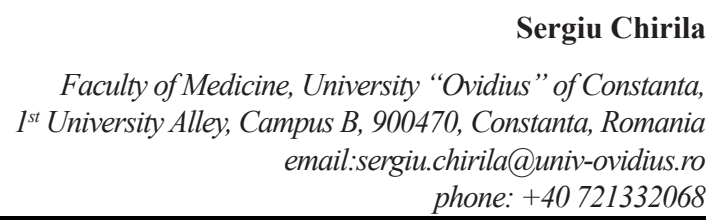

\section{ABSTRACT}

The Vitamin D deficiency could be involved in the development of psoriasis, Vitamin D defficiency being considerd to be involved in the development of disorders related to cellular immune system. The aim of this study is to review the literature in order to find if there is an association between the Vitamin $D$ level in the serum and psoriasis. A search for relevant articles was performed using PubMed, Web of Science and Springer databases. A total of 19 articles fulfilled the criteria for inclusion in this review. 14 studies revealed statistically significant lower levels of Vitamin D in psoriatic patients when compared to healthy controls. The other 5 studies did not found a statistically significant difference between 25-hydroxycholecalciferol levels in psoriasis group and in control group.

Keywords: vitamin D, psoriasis, 25-hydroxy vitamin D level, 25-hydroxycholecalciferol

\section{Introduction}

Psoriasis represents a complex, immunemediated systemic disease, which is influenced by environmental factors and genetic ones. These factors contribute to its development and phenotypic expression. Although, historically was considered as a skin-limited disease, psoriasis is now known to be a disorder of systemic inflamation, associated with inflamatory arthritis, and increasingly understood to be associated with cardiovascular diseases and metabolic syndrome (1)supplementary and total vitamin D intake and incident psoriasis in women. A prospective study was performed of 70,437 US female nurses aged
47-74 enrolled in the Nurses' Health Study who did not have psoriasis at baseline in 1994 and who completed semi-quantitative food frequency questionnaires in 1994, 1998, 2002 and 2006. The incidence of clinician-diagnosed psoriasis was ascertained and validated by self-reported questionnaires. 502 confirmed incident psoriasis cases were documented during 973.057 personyears of follow-up from 1994 June to 2008 June. Association between vitamin D intake and incident psoriasis was assessed using multivariableadjusted cox regression analysis. After adjusting for age, smoking, body mass index, calorie intake, UV fl ux, exercise and alcohol use, there was no signifi cant association between vitamin $\mathrm{D}$ intake 
(dietary, supplementary and total vitamin D. The pathogenesis of psoriasis is not completely known (2). In psoriasis, all therapeutic strategies aim to reduce the symptoms and the burden of the disease.

Topical corticosteroids are used generaly for controling mild symptoms. Also, other interventions are vitamin D and their analogs supplementation, or other local antiinflammatory ointments. Phototherapy and systemic immunosuppresants are generally used for severe cases (3)however, requires several hospital visits weekly, interfering with (school.

Vitamin $\mathrm{D}$ is an oil-soluble vitamin implicated in calcium absorption, bone metabolism,calciumandphosporoushomeostasis, skeletal mineralization and it also has numerous other metabolic and physiological functions. UVB exposure helps keratinocytes from the epidermis to synthesize previtamin D3 which is later converted to the active form of vitamin $\mathrm{D}$, known as 1,25 dihydroxycholecalciferol. The levels of vitamin D from the serum are changing with the season. Maximum values are reached in the seasons with high sun exposure, while in the seasons with low sun exposured, the levels reach minimum values (2). The reference values for vitamin $\mathrm{D}$ (25-hydroxycholecalciferol) are considered to be $30-50 \mathrm{ng} / \mathrm{ml}(75-125 \mathrm{nmol} / \mathrm{l})$. Values less than $20 \mathrm{ng} / \mathrm{ml}(50 \mathrm{nmol} / \mathrm{l})$ indicate Vitamin D deficiency (4)and vitamin D analogs are widely used in its treatment. It is evident that ultraviolet radiation enables vitamin D-3 (cholecalciferol. Low serum levels of $25-\mathrm{OH}$ vitamin $\mathrm{D}$ have been reported in numerous diseases such as cardiovascular diseases (5), autoimmune diseases, malignancies, multiple sclerosis, metabolic disorders, inflammatory bowel disease or psoriasis (6).

Vitamin D has many roles, evidence suggesting that vitamin $\mathrm{D}$ can modulate the activity in dendritic cells and keratinocytes and the proliferation in T-cells. All metabolites of vitamin $\mathrm{D}$ act via the vitamin $\mathrm{D}$ receptors. One of the metabolites, 25-hydroxycholecalciferol, has double activity in keratinocytes: inhibition of their proliferation and enhacement of the maturity. Taking this influence on the keratinocytes into consideration, a deficiency in 25-hydroxycholecalciferol might be a risk factor in the development of psoriasis, with possible implications in disorders related to cellular immune system and angiogenesis. Some theories consider that psoriasis could activate a vicious circle with severe deterioration of cutaneous functions and, furthermore, a progressive decline of vitamin $\mathrm{D}$ derivatives levels in the whole body (4)and vitamin D analogs are widely used in its treatment. It is evident that ultraviolet radiation enables vitamin D-3 (cholecalciferol.

The aim of this study was to review the literature for studies comparing the $25 \mathrm{OH}$ vitamin levels in patients with psoriasis compared to healthy controls.

\section{Material and methods}

We searched for relevant articles on PubMed, Web of Science and Springer, by using „Vitamin D” and „Psoriasis” as keywords. For inclusion in our study, the following criterion was set: comparison between the vitamin D serum level in psoriatic patients and in healthy controls. It were taken into consideration either retrospective studies, or prospective studies. The studies that were lacking healthy human controls were excluded.

After searching PubMed, Web of Science, and Scopus for the keywords, after the screening, over one thousand unique, eligible articles were identified (Figure 1). After applying the inclusion and the exclusion criteria, 19 articles were considered eligible for this review.

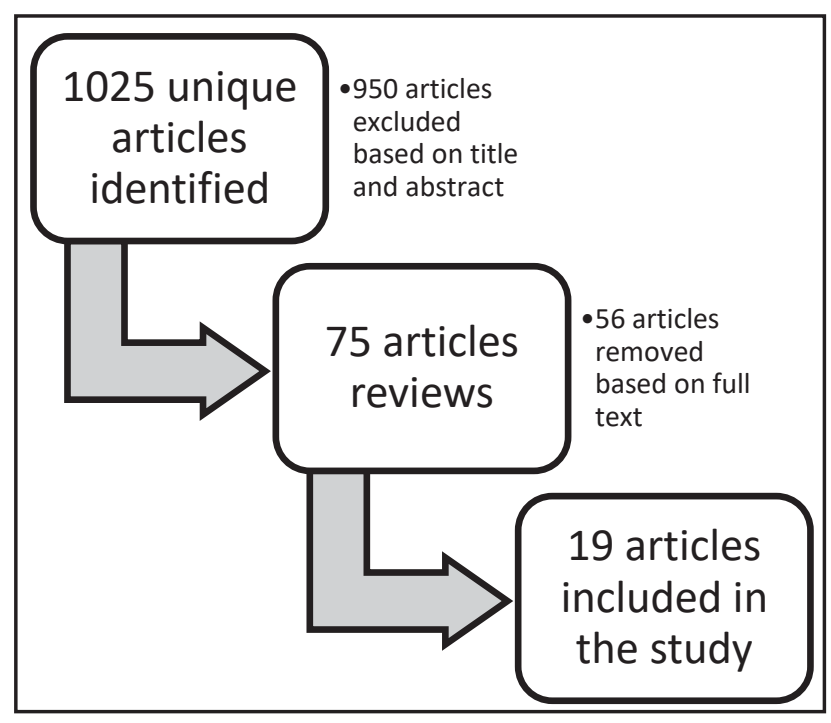

Figure 1 Flow diagram of study selection 
Table 1 Studies with statistically significant difference

\begin{tabular}{|c|c|c|}
\hline Authors & Sample & Main Results \\
\hline $\begin{array}{l}\text { Chandrashekar, } \\
\text { L., } 2015 \text { (7) }\end{array}$ & $\begin{array}{l}43 \text { psoriatic patients } \\
43 \text { healthy controls }\end{array}$ & $\begin{array}{l}\text { Vitamin D level was significantly lower in the psoriasis patients group }(13.3 \pm \\
6.9 \mathrm{vs} 22.4 \pm 18.4, \mathrm{p}=0.004) \text {, concluding that psoriasis is associated with lower } \\
\text { vitamin D levels and high levels of inflammation markers such as hs-CRP and } \\
\text { ischemia-modified albumin. }\end{array}$ \\
\hline $\begin{array}{l}\text { Myśliwiec, H., } \\
2016(8)\end{array}$ & $\begin{array}{l}115 \text { patients with exacerbated plaque } \\
\text { type psoriasis, } 38 \text { healthy persons }\end{array}$ & $\begin{array}{l}\text { The study revealed that serum } 25-\mathrm{OH} \text { vitamin D levels were decreased in both } \\
\text { groups, but a higher prevalence of defficiency was observed in the psoriasis } \\
\text { group }(66 \% \text { vs } 24 \% \text { during the summer and } 66 \% \text { vs } 71 \% \text { during the winter) } \\
\text { ( } \mathrm{p}=0.0003) \text {. } \\
25-\mathrm{OH} \text { vitamin D serum concentrations of psoriatic patients were significantly } \\
\text { lower compared to the control group ( } \mathrm{p}=0,0003 \text { ). } \\
\text { Exposure to UVB, serum } 25-\mathrm{OH} \text { vitamin D levels increased and the PASI score } \\
\text { improved. }\end{array}$ \\
\hline $\begin{array}{l}\text { Filoni, A., } \\
2018(9)\end{array}$ & $\begin{array}{l}170 \text { psoriatic patients } \\
51 \text { patients with autoimmune bullous } \\
\text { disease, } 340 \text { healthy controls }\end{array}$ & $\begin{array}{l}\text { 25-OH Vitamin D serum level differ }(\mathrm{p}=0.0001) \text { among the three groups. In } \\
\text { patients with psoriasis the levels were significantly lower compared to healthy } \\
\text { controls }(18.2 \pm 11.1 \mathrm{ng} / \mathrm{mL} \text { vs } 34.3 \pm 13.3 \mathrm{ng} / \mathrm{mL})(\mathrm{p}=0.0007) \text {. }\end{array}$ \\
\hline $\begin{array}{l}\text { Orgaz-Molina, } \\
\text { J., } 2014(10)\end{array}$ & $\begin{array}{l}46 \text { patients with psoriasis, without } \\
\text { arthritis and systemic treatment } \\
46 \text { control subjects }\end{array}$ & $\begin{array}{l}\text { Significantly lower } 25-\mathrm{OH} \text { Vitamin } \mathrm{D} \text { levels in psoriatic patients compared to } \\
\text { control subjects }(30.5 \pm 9.3 \mathrm{vs} .38 .3 \pm 9.6 \mathrm{ng} / \mathrm{mL} ; \mathrm{p}=0.0001) \\
\text { Lower than } 30 \mathrm{ng} / \mathrm{mL} \text { values were observed in } 54.4 \% \text { of psoriasis group vs. } \\
22.6 \% \text { in the control group }(\mathrm{p}<0.001) .\end{array}$ \\
\hline $\begin{array}{l}\text { Mattozzi, C. } \\
2018 \text { (11) }\end{array}$ & $\begin{array}{l}141 \text { caucasian subjects with } \\
\text { moderate to severe psoriasis, } 62 \\
\text { healthy controls }\end{array}$ & $\begin{array}{l}\text { Patients with psoriasis presented lower values of } 25-\mathrm{Oh} \text { vitamin D compared to } \\
\text { healthy controls. }\end{array}$ \\
\hline $\begin{array}{l}\text { Ricceri, F., } \\
2013(12)\end{array}$ & $\begin{array}{l}68 \text { patients with chronic plaque } \\
\text { psoriasis } \\
60 \text { healthy controls } \\
\end{array}$ & $\begin{array}{l}\text { Psoriasis patients group presented significanlty lower levels of } 25-\mathrm{OH} \text { vitamin } \\
\mathrm{D}(\mathrm{p}<0.05) . \text { Most of them had Vitamin D levels lower than normal, } 97 \% \text { with } \\
\text { defficiency and } 68 \% \text { with insufficiency.j }\end{array}$ \\
\hline $\begin{array}{l}\text { Orgaz-Molina, } \\
\text { J., } 2012 \text { (13) }\end{array}$ & $\begin{array}{l}43 \text { patients with psoriasis } 43 \text { control } \\
\text { subjects }\end{array}$ & $\begin{array}{l}\text { 25-OH vitamin } \mathrm{D} \text { serum concentration was significantly lower in the psoriasis } \\
\text { patients group }(24.41 \pm 7.80 \text { vs } 29.53 \pm 9.38 ; \mathrm{P}=0.007) \text {. } \\
\text { One quarte of the patients within psoriasis group were Vitamin D deficient } \\
(25,6 \%) \text { compare to } 9.3 \% \text { in the comparison group }(\mathrm{p}=0.043) ; 79.1 \% \text { of the } \\
\text { patients reented Vidamin D insufficiency, verss } 58,1 \% \text { in the control group } \\
(\mathrm{p}=0,037) .\end{array}$ \\
\hline $\begin{array}{l}\text { Al-Mutairi, } \\
\text { N.,2014 (14) }\end{array}$ & $\begin{array}{l}93 \text { psoriasis patients } \\
50 \text { controls }\end{array}$ & $\begin{array}{l}25-\mathrm{OH} \text { vitamin } \mathrm{D} \text { was } 31.5 \pm 14.41 \mathrm{nmol} / \mathrm{L} \text { in the patient group and } 53.5 \pm \\
19.6 \mathrm{nmol} / \mathrm{L} \text { in controls }(\mathrm{p}=0.015) .\end{array}$ \\
\hline $\begin{array}{l}\text { Al-Mutairi, N., } \\
2013(15)\end{array}$ & \begin{tabular}{|l|}
100 patients with stable plaque \\
psoriasis (psoriasis area and severity \\
index $\geq 10$ ) with no systemic \\
treatment in the past 3 months \\
100 healthy volunteers
\end{tabular} & $\begin{array}{l}\text { 25-OH vitamin } \mathrm{D} \text { concentration was } 29.53 \mathrm{nmol} / \mathrm{L} \pm 9.38 \mathrm{nmol} / \mathrm{L} \text { in patients, } \\
\text { and } 53.5 \mathrm{nmol} / \mathrm{L} \pm 19.6 \mathrm{nmol} / \mathrm{L} \text { in healthy controls }(\mathrm{p}<0.0001) .\end{array}$ \\
\hline $\begin{array}{l}\text { Amon, U., } \\
2018(16)\end{array}$ & $\begin{array}{l}\text { Subgroup a (1461 patients with } \\
\text { clear diagnoses of skin diseases or } \\
\text { allergies, among which } 180 \text { with } \\
\text { psoriasis vulgaris) } \\
\text { Subgroup b (71 healty controls) }\end{array}$ & $\begin{array}{l}\text { The mean value for } 25-\mathrm{OH} \text { Vitamin D level in psoriasis patients was } 22,6 \mathrm{ng} / \\
\mathrm{ml} \text {, ith SD of } 10,7 \mathrm{ng} / \mathrm{ml} ; 43.8 \% \text { presented Vidamin d defficiency. } \\
\text { The healthy group had a mean value of } 44,1 \mathrm{ng} / \mathrm{ml} \text { with SD of } 10.7 \mathrm{ng} / \mathrm{ml} \text {, with } \\
1.4 \% \text { being Vitamin D defficient. Significance level for the difference, } \mathrm{p}<0,001 \text {. }\end{array}$ \\
\hline $\begin{array}{l}\text { Bergler-Czop, } \\
\text { B., } 2016(4)\end{array}$ & $\begin{array}{l}40 \text { adults with psoriasis } \\
40 \text { healthy subjects }\end{array}$ & $\begin{array}{l}\text { Average } 25-\mathrm{OH} \text { Vitamin D values for study group was } 32,25 \mathrm{nmol} / 1 \text {, with sd } \\
6,79 \mathrm{nmol} / 1 \text { while in the control group, the mean value was } 57,62 \mathrm{nmol} / 1 \text { with sd } \\
\text { of } 6,82 \mathrm{nmol} / 1 \text { ( } \mathrm{p}=0.048) \text {. } \\
\text { For both groups, most of the subjects were vitamin D deficient. }\end{array}$ \\
\hline $\begin{array}{l}\text { Orgaz-Molina, } \\
\text { J., } 2014 \text { (17) }\end{array}$ & $\begin{array}{l}44 \text { psoriatic patients without arthritis } \\
44 \text { controls }\end{array}$ & $\begin{array}{l}\text { 25-OH vitamin D level for study group was } 29.92 \mathrm{ng} / \mathrm{mL} \text {, significantly lower } \\
\text { compared to control group, } 38.00 \mathrm{ng} / \mathrm{mL}, \mathrm{p}<0.0001 \text {. }\end{array}$ \\
\hline $\begin{array}{l}\text { Gisondi, P., } \\
2012(18)\end{array}$ & \begin{tabular}{|l|}
145 patients with chronic plaque \\
psoriasis \\
112 patients with rheumatoid arthritis \\
(RA) \\
141 healthy controls
\end{tabular} & $\begin{array}{l}\text { The levels of } 25-\mathrm{OH} \text { Vitamin D differ significantly among the three groups } \\
(\mathrm{p}=0.001) \text {, with mean values of } 20.7 \pm 11.3 \text { (psoriasis group), } 24.0 \pm 11.4 \\
\text { (rheumatoid arthritis groups) and } 37.1 \pm 27.6 \text { in control group. } \\
\text { The vitamin D levels were significantly lower in psoriatic patients group } \\
\text { compared to control group }(\mathrm{p}=0.01) \text {. }\end{array}$ \\
\hline $\begin{array}{l}\text { Atwa, M. A., } \\
2013(19)\end{array}$ & $\begin{array}{l}43 \text { patients with plaque psoriasis } \\
55 \text { rheumatoid arthritis patients } \\
40 \text { healthy controls matched for age }\end{array}$ & $\begin{array}{l}\text { Values for } 25-\mathrm{OH} \text { Vitamin } \mathrm{D} \text { were statistically different among the three groups } \\
(\mathrm{p}<0.001) . \\
(11.74 \pm 3.60 \mathrm{ng} / \mathrm{ml} \text { in psoriasis group, } 15.45 \pm 6.42 \mathrm{ng} / \mathrm{ml} \text { in rheumatoid arthritis } \\
\text { group, and } 24.55 \pm 11.21 \mathrm{ng} / \mathrm{ml} \text { in control group). }\end{array}$ \\
\hline
\end{tabular}


Total number of people assesed was 10068 , stratified as follows: 1593 patients with psoriasis, 1499 patients with other diseases and 6976 healthy controls.

\section{Results}

From the studies included in the review, 14 of them revealed a statistically significant difference between the vitamin $\mathrm{D}$ serum level in psoriatic patients and in healthy controls. These studies are presented in Table 1. In the remaining 5 studies, the difference between the vitamin D serum level from psoriatic patients and from healthy group was not statistically significant. These studies are described in Table 2.

\section{Discussion}

In all the 14 studies that revealed a statistically significant difference between the vitamin D serum level among the compared groups, the vitamin D levels were lower in the psoriatic patients group.

Chandrashekar et al. found that 25-hydroxy vitamin D serum levels were significantly lower in psoriasis cases. Psoriasis severity, assessed by using PASI score, correlated negatively with serum levels of 25-OH vitamin D (7). Myśliwiec et al. observed vitamin $\mathrm{D}$ deficiency both in psoriatic patients and in the control group with significantly lower values in the first group. The prevalence of the deficiency among psoriatic patients was higher compared to the control group, especially during summer. Also, the 25-hydroxy vitamin D level increased after UVB phototherapy (8)in between psoriasis. Vitamin D regulates function of the dendritic cells, proliferation and maturation of the keratynocytes and lymphocytes $\mathrm{T}$. The aim of the study was to evaluate serum vitamin D (250HD.

Filoni et al. revealed the relationship of vitamin D serum level with the age of the patient, the season when measured and the time from the start of the disease. They also found that $45.8 \%$ of psoriasis patients had vitamin D deficiency $(<20$ $\mathrm{ng} / \mathrm{mL}$ ) and $38.9 \%$ had vitamin D insufficiency (20-30ng/mL) (9).

Orgaz-Molina et al. compared in 2014 46 psoriatic patients, without arthritis and 46 control subjects. They found significantly lower levels of $25-\mathrm{OH}$ vitamin $\mathrm{D}$ in the patients group. Furthermore, in the psoriatic group serum $25-\mathrm{OH}$ vitamin D levels were significantly and negatively correlated with some metabolic syndrome criteria. Thus, psoriatic patients with metabolic syndrome showed a significantly lower level of $25-\mathrm{OH}$ vitamin $\mathrm{D}$ than patients without metabolic syndrome (10). In 2012, Orgaz-Molina et al. compared 43 psoriatic patients and 43 control subjects and found that serum $25-\mathrm{OH}$ vitamin D levels were lower in psoriatic patients, even after adjusting for confounding factors. They did not found a significant correlation between $25-\mathrm{OH}$

Table 2 Studies with non-statistically significant difference

\begin{tabular}{|c|c|c|}
\hline Authors & Sample & Results \\
\hline $\begin{array}{l}\text { Solak, B., } \\
2016(20)\end{array}$ & $\begin{array}{l}43 \text { patients with psoriasis, } \\
\text { without arthritis and } 41 \text { healty } \\
\text { controls, less than } 50 \text { years old. }\end{array}$ & $\begin{array}{l}\text { No significant difference was observed for men, } 26.6 \pm 8.6 \mathrm{nmol} .1 \text { (psoriasis group) } \\
\text { vs } 22.2 \pm 10.1 \mathrm{nmol} / 1 \text { (control group), } \mathrm{p}=0.272 \text {. In females the vitamin } \mathrm{D} \text { level was } \\
\text { significantly lower } 18 \pm 7.3 \mathrm{nmol} / 1 \text { vs } 27.1 \pm 15.9 \mathrm{nmol} .1(\mathrm{p}=0.012) \text {. Overall, the } \\
\text { difference was not statistically significant }(\mathrm{p}=0.12)\end{array}$ \\
\hline $\begin{array}{l}\text { Nayak, P., } \\
2018 \text { (21) }\end{array}$ & $\begin{array}{l}\text { Hospital-based case-control. } 61 \\
\text { patients with psoriasis and } 61 \\
\text { age and sex matcheed controls. }\end{array}$ & $\begin{array}{l}86.9 \% \text { of patients with psoriasis and } 83.6 \% \text { of controls had lower levels of vitamin } \\
\text { D. No statistically significant difference was observed }(p=0.1) \text {. Both case group and } \\
\text { control group had low levels of vitamin D. }\end{array}$ \\
\hline $\begin{array}{l}\text { Wilson, P., } \\
2013 \text { (22) }\end{array}$ & $\begin{array}{l}\text { Population based study, 20-59 } \\
\text { years old, self-reported with } \\
\text { psoriasis }\end{array}$ & $\begin{array}{l}\text { Mean } 25-\mathrm{OH} \text { vitamin } \mathrm{D} \text { was } 24.2 \mathrm{ng} / \mathrm{mL} \text { and } 23.6 \mathrm{ng} / \mathrm{mL} \text { for participants with and } \\
\text { without psoriasis }(\mathrm{P}=0.37) \text {. More than } 70 \% \text { of the participants, in both groups were } \\
\text { vitamin D defficient, and } 33 \% \text { of psorisis patients and } 34.9 \% \text { from control group } \\
\text { were Vitamin D defficient. }\end{array}$ \\
\hline $\begin{array}{l}\text { Maleki, M., } \\
2016 \text { (23) }\end{array}$ & $\begin{array}{l}\text { Cross-sectional study, } \\
\text { dermatology clinic, } 50 \text { psoriatic } \\
\text { patients and } 43 \text { healty controls. }\end{array}$ & $\begin{array}{l}\text { The mean serum vitamin } \mathrm{D} \text { level, for participants with psoriasis was } 14.92 \pm 6.31 \\
\mathrm{ng} / \mathrm{mL} \text { while in the control group, it was } 12.52 \pm 4.54 \mathrm{ng} / \mathrm{ml} \text {.. The difference was not } \\
\text { statistically significant }(\mathrm{P}=0.21) \text {. The prevalence of Vitamin } \mathrm{D} \text { defficiency was } 84 \% \\
\text { in psoriatic patients group and } 93 \% \text { in control group. }\end{array}$ \\
\hline $\begin{array}{l}\text { Zuchi, M.F., } \\
2015 \text { (24) }\end{array}$ & $\begin{array}{l}20 \text { psoriatic patients, aged } 19 \text { to } \\
76 \text { compared with } 20 \text { patients } \\
\text { aged } 1 \text { to } 84 .\end{array}$ & $\begin{array}{l}\text { The median vitamin D serum level in the psoriasis cases was } 23.55 \pm 7.6 \mathrm{ng} / \mathrm{ml} \\
\text { and in the controls was } 22.35 \pm 3.10 \mathrm{ng} / \mathrm{ml}(\mathrm{p}=0.73) \text {. Percentage of patients with } \\
\text { Vitamin D deficiency and insufficiency was almost equal }(5 / 20 \mathrm{vs} 4 / 20 \text { and } 13 / 20 \mathrm{vs} \\
12 / 20) \text {. In the psoriasis patients group, males had higher levels of Vitamin D when } \\
\text { compared to females }(25.35 \pm 2.9 \text { vs } 20.85 \pm 6.7, \mathrm{p}=0.0317 \text {. }\end{array}$ \\
\hline
\end{tabular}


vitamin D levels and psoriasis manifestations evaluated thropugh PASI score, mean time with psoriasis, or other chronic diseases (13)including systemic lupus erythematosus, rheumatoid arthritis, diabetes mellitus, and multiple sclerosis. Objective: The main objective of this study was to analyze the 25-hydroxyvitamin D (OHD.

Mattozzi et al. obtained a similar results, with vitamin $\mathrm{D}$ levels lower in psoriatic patients and vitamin $\mathrm{D}$ levels with negative correlation with the clinical severity of the disease (11). Ricceri et al. found that serum $25-\mathrm{OH}$ vitamin D had significant negative correlations with PASI score $(\mathrm{P}<0.001)$ (12).

Al-Mutairi et al. concluded that serum levels of vitamin D were significantly lower in psoriatic patients than in healthy persons (15) a lot of co-morbidities (diabetes, obesity, heart disease, etc.. Furthermore, there was a highly significant elevation of serum $25-\mathrm{OH}$ vitamin D and serum LL-37 among psoriasis patients after narrowband ultraviolet B treatment (14).

Amon et al. found that serum level of 25$\mathrm{OH}$ vitamin $\mathrm{D}$ was significantly lower in psoriatic subgroup compared to the healthy subgroup $(p<0.001)$. They did not find a correlation between quality of life, as measured by the Dermatology Life Quality Index, and 25-OH vitamin D levels for patients with psoriasis. The percentage of psoriatic patients with vitamin D serumlevel lower than $20 \mathrm{ng} / \mathrm{mL}$ was $43.9 \%$ (16). Bergler-Czop et al. revealed a statistically significant difference in 25-hydroxycholecalciferol level between patients with psoriasis and healthy individuals. The level of 25-hydroxycholecalciferol was seriously deficient in both groups. Also, it was found a negative correlation of vitamin $\mathrm{D}$ serum level with both PASI $(\mathrm{r}=-0.43)$ and the duration of psoriasis $(r=-0.53)$ (4)and vitamin $\mathrm{D}$ analogs are widely used in its treatment. It is evident that ultraviolet radiation enables vitamin D-3 (cholecalciferol.

Orgaz-Molina et al. analyzed the association between 25-hydroxy vitamin D serum levels and subclinical carotid atherosclerosis in psoriasis patients and found a significant negative correlation between serum $25-\mathrm{OH}$ vitamin D levels and the Maximal Intima-Media Thickness ( $r s=-0.678, p<0.0001)$. No correlation was found in healthy controls. Also, serum levels of vitamin
D were significantly lower $(p=0.003)$ in psoriatic patients with carotid atheromatous plaque than in those without it. Moreover, serum 25-OH vitamin $D$ showed an inverse correlation with age $(\mathrm{rs}=-$ $0.499, p=0.001$ ), Body Mass Index ( $r s=-0.300$, $\mathrm{p}=0.048)$, total cholesterol $(\mathrm{rs}=-0.475, \mathrm{p}=0.001)$, low density lipoprotein cholesterol $(\mathrm{rs}=-0.465$, $\mathrm{p}=0.001)$ and triglycerides $(\mathrm{rs}=-0.396, \mathrm{p}=0.008)$ levels (17).

Gisondi et al. established that the $25-\mathrm{OH}$ vitamin $\mathrm{D}$ levels were lower in patients with psoriasis when compared with healthy controls, while no difference between patients with psoriasis and those with rheumatoid arthritis. Furthermore, 25-OH vitamin D sergum levels showed high seasonal variability. Serum levels of vitamin $\mathrm{D}$ at patients with psoriasis $(\mathrm{ng} / \mathrm{mL})$ were $19.1 \pm 7.6$ in spring, $27 \pm 14.5$ in summer, $20.1 \pm 12.6$ in autumn and $16 \pm 10.5$ in winter $(\mathrm{P}<0.01)$ (18). Atwa et al. found a significant difference in $25-\mathrm{OH}$ vitamin $\mathrm{D}$ level among the psoriatic patients group and the healthy controls group. They also found that $25-\mathrm{OH}$ vitamin D serum level was not correlated with PASI, DAS28 (Disease activity score index of a 28 joint count), TNF-a, CRP (C-reactive protein) or ESR (erythrocyte sedimentation rate) in psoriatic patients (19).

From all the 19 studies included in this review, 5 of them did not reveal a statistically significant difference between the vitamin D level in psoriatic patients and in healthy controls. Among these 5 studies, only one revealed lower levels of vitamin $\mathrm{D}$ in psoriatic patients compared with healthy controls, while in the other four studies the psoriatic patients had higher vitamin D levels than healthy persons. Also, we must acknowledge the fact that in all these five studies, the vitamin D levels were lower than normal, in high proportion of the subjects, from both study groups (case group and control group).

Solak et al. compared 43 psoriasis patients without arthritis and 41 healthy persons and found that the percentage of overall osteopenia and osteoporosis was significantly higher in patients with psoriasis when compared with the control group, but there was not a significant difference between the two groups regarding serum vitamin D levels (20). Nayak et al. revealed that vitamin D levels were significantly lower in females 
when compared to males in both psoriasis cases $(\mathrm{P}=0.02)$ and controls $(\mathrm{P}=0.006)$. Also, there was not a significant correlation between the severity of the disease and serum levels of vitamin D, calcium and C-reactive protein (20).

Wilson found that Psoriasis Life Impairment was not associated with $25-\mathrm{OH}$ vitamin $\mathrm{D}$, but Body Mass Index had an inverse association with 25-OH vitamin D level (coefficient $=-0.40$, $\mathrm{P}<0.001$ ) (22). Maleki et al. concluded that serum $25-\mathrm{OH}$ vitamin $\mathrm{D}$ did not correlate with family history $(\mathrm{P}=0.92)$ or with joint $(\mathrm{P}=0.53)$ or nail $(\mathrm{P}=0.27)$ involvement, but it did correlate with female gender $(\mathrm{P}=0.04)$ and higher PASI score $(\mathrm{P}=0.03)$ (23). Zuchi et al. did not find significant differences in vitamin $\mathrm{D}$ serum levels between psoriasis patients and healthy controls $(P=0.735)$, but they find vitamin $\mathrm{D}$ serum to be lower in women with psoriasis when compared to men with psoriasis ( $\mathrm{P}=0.03)$, difference that was not statistically significant among healthy controls $(p=0.62)(24)$.

\section{Conclusions}

From our review we conclude that the vitamin D levels in psoriatic patients tend to be lower when compared to non-psoriatic patients. Also, even in the case of the studies in which a difference was not observed, most of the participants had lower than normal levels for Vitamin D.

\section{References}

1. Merola JF, Han J, Li T, Qureshi AA. No association between vitamin $\mathrm{D}$ intake and incident psoriasis among US women. Archives of Dermatological Research. 2014;306(3):305-7.

2. Al-Dhubaibi MS. Association between Vitamin D deficiency and psoriasis: An exploratory study. International Journal Of Health Sciences-IJHS. 2018;12(1):33-9.

3. Franken SM, Witte B, Pavel S, Rustemeyer T. Psoriasis and daily low-emission phototherapy: effects on disease and vitamin D level. Photodermatology Photoimmunology \& Photomedicine. 2015;31(2):83-9.

4. Bergler-Czop B, Brzezińska-Wcisło L. Serum vitamin D level - the effect on the clinical course of psoriasis. Advances in Dermatology and Allergology. 2016;6(6):445-9.

5. Condur L, Chirila S. The relationship between Vitamin d and cardiovascular risk. Medicro. 2018 (122):8-12.

6. Hambly R, Kirby B. The relevance of serum vitamin $\mathrm{D}$ in psoriasis: a review. Archives of Dermatological Research. 2017;309(7):499517.

7. Chandrashekar L, Krishna Kumari GR, Rajappa M, Revathy G, Munisamy M, Thappa DM. 25-hydroxy Vitamin D and ischaemia-modified albumin levels in psoriasis and their association with disease severity. British Journal of Biomedical Science. 2015;72(2):56-60.

8. Myśliwiec H, Kiluk P, ŻelazowskaRutkowska B, Baran A, Justyna Milewska A, Myśliwiec P, et al. Vitamin D deficiency in psoriatic patients in north-east of Poland. Przeglad lekarski. 2016;73(9):610-4.

9. Filoni A, Vestita M, Congedo M, Giudice G, Tafuri S, Bonamonte D. Association between psoriasis and Vitamin D: Duration of disease correlates with decreased Vitamin D serum levels: An observational case-control study. Medicine (United States). 2018;97(25).

10. Orgaz-Molina J, Magro-Checa C, ArrabalPolo MA, Raya-Alvarez E, Naranjo R, Buendia-Eisman A, et al. Association of 25-hydroxyvitamin D with Metabolic Syndrome in Patients with Psoriasis: A Casecontrol Study. Acta Dermato-Venereologica. 2014;94(2):142-5.

11. Mattozzi C, Paolino G, Salvi M, Macaluso L, Scarno M, De Vita G, et al. Correlation between plasmatic levels of vitamin $\mathrm{D}$ and PASI score. Giornale ItalianoDiDermatologia E Venereologia. 2018;153(2):155-60

12. Ricceri F, Pescitelli L, Tripo L, Prignano F. Deficiency of serum concentration of 25-hydroxyvitamin D correlates with severity of disease in chronic plaque psoriasis. Journal Of The American Academy Of Dermatology. 2013;68(3):511-2.

13. Orgaz-Molina J, Buendia-Eisman A, ArrabalPolo MA, Carlos Ruiz J, Arias-Santiago S. Deficiency of serum concentration of 25-hydroxyvitamin D in psoriatic patients: A 
case-control study. Journal Of The American Academy Of Dermatology. 2012;67(5):9318.

14. Al-Mutairi N, Shaaban D. Effect of Narrowband Ultraviolet B Therapy on Serum Vitamin D and Cathelicidin (LL-37) in Patients with Chronic Plaque Psoriasis. Journal Of Cutaneous Medicine And Surgery. 2014;18(1):43-8.

15. Al-Mutairi N, El Eassa B, Nair V. Measurement of vitamin D and cathelicidin (LL-37) levels in patients of psoriasis with co-morbidities. INDIAN JOURNAL OF Dermatology Venereology \& Leprology. 2013;79(4):492-6.

16. Amon U, Baier L, Yaguboglu R, Ennis M, Holick MF, Amon J. Serum 25-hydroxyvitamin D levels in patients with skin diseases including psoriasis, infections, and atopic dermatitis. DermatoEndocrinology. 2018;10(1).

17. Orgaz-Molina J, Magro-Checa C, RosalesAlexander JL, Arrabal-Polo MA, CastelloteCaballero L, Buendía-Eisman A, et al. Vitamin D insufficiency is associated with higher carotid intima-media thickness in psoriatic patients. European Journal of Dermatology. 2014;24(1):53-62.

18. Gisondi P, Rossini M, Di Cesare A, Idolazzi L, Farina S, Beltrami G, et al. Vitamin D status in patients with chronic plaque psoriasis. British Journal of Dermatology. 2012;166(3):505-10.

19. Atwa MA, Balata M, Abdelrahman N, Hussein A, Kareem H. Vitamin D status in patients with psoriasis and rheumatoid arthritis; association with disease activity and serum level of TNF-alpha. JOURNAL OF THE EUROPEAN ACADEMY OF Dermatology And Venereology. 2013;27(4, SI):32-3.

20. Solak B, Dikicier BS, Celik HD, Erdem T. Bone Mineral Density, 25-OH Vitamin D and Inflammation in Patients with Psoriasis. Photodermatology Photoimmunology \& Photomedicine. 2016;32(3):153-60.

21. Nayak PB, Girisha BS, Noronha TM, Sripathi H. Low Vitamin D in Psoriasis: Reality or Myth? Indian Journal Of Dermatology. 2018;63(3):255-60.
22. Wilson PB. Serum 25-hydroxyvitamin $\mathrm{D}$ status in individuals with psoriasis in the general population. Endocrine. 2013;44(2):537-9.

23. Maleki M, Nahidi Y, Azizahari S, Meibodi NT, Hadianfar A. Serum 25-OH Vitamin D Level in Psoriatic Patients and Comparison With Control Subjects. Journal of Cutaneous Medicine and Surgery. 2016;20(3):207-10.

24. Zuchi MF, Azevedo PdO, Tanaka AA, Schmitt JV, Martins LEAM. Serum levels of 25-hydroxy vitamin $\mathrm{D}$ in psoriatic patients. Anais Brasileiros de Dermatologia. 2015;90(3):430-2. 